\title{
DRAMA INTERPRETATION OF THE FAIRY TALE THE SNOW QUEEN BY HANS CHRISTIAN ANDERSEN
}

\author{
Olimpia Gogolin
}

\author{
Eugeniusz Szymik \\ University of Silesia in Katowice, Poland
}

\begin{abstract}
The theoretical part introduces the most frequently used drama techniques in early school education of Polish language. The practical part presents drama interpretation of the fairy tale The Snow Queen by Hans Christian Andersen. In the article, drama is introduced as a method that triggers students' creative expression, which helps them understand the literary text better and ask proper questions.
\end{abstract}

Keywords: fairy tale, H.Ch. Andersen, drama method, the Polish language early childhood education.

\section{Introduction}

Hans Christian Andersen - considered to be the "master of literary fables" (Kuliczkowska \& Tylicka [eds.], 1979, p. 27) - was born on 2 April 1805 in Odense, and died on 4 August 1875 in Copenhagen. He wrote numerous poems, comedies, and dramas, but he was most well known for his fairy tales, full of humanity, which were translated into more than 80 languages.

"The life, personality, and visual appearance of Andersen arouse interest, induce empathy and encourage to learn about the life and artistic situation of the author - to get in his shoes, examine the facts and the era, capture significant features of the man, who still wanted more, suffered mentally and physically, but was also acknowledged" (Ogłoza, 2014, pp. 7-8).

Andersen started writing The Snow Queen on 5 December 1844, and completed it only five days later. According to Ewa Ogłoza, quoted above, the author of the book Wokót opowieści Hansa Christiana Andersena. O radości czytania (Around the stories of Hans Christian Andersen. On the joy of reading), this fairy tale is composed of two myths: the myth of Gerda, whom Papuzińska identified as "an extraordinary child with a warm, loving heart, created in order to <<bury the source of evil >>, capable of the greatest sacrifices, radiating love so powerful that it is capable of overcoming all obstacles" (Papuzińska, 1997, pp. 
40-45), as well as the myth of "Kays-Cains", whose vision of the world is full of despair, disgust and the desire to escape.

From a set books addressed to the young reader, we chose one of the fairy tales for the purposes of the drama activities, due to the presence of these fairy tales in the core curriculum for Polish language early childhood education. Teaching practice suggests that third grade students usually gladly reach for this literary genre, since their attention in fairy tales is drawn by: intriguing plot, lively and fast action, and fascinating adventures of the protagonists, filled with dangers. At this age, pupils are particularly sensitive to the charm of the world of magic. In addition, lessons covering fairy tales provide them with strong emotions, since during those lessons, the students not only listen to the fairy tale, but also tell stories and express their emotions. Fairy tales - as a "philosophy of life, the deepest wisdom in the most available form" (Tuszyńska-Chechłacz, 1986, p. 340) - help "build self-confidence, integrate with the world, build the capacity to maintain significant and permanent bonds with people" (Laskowska, 2007, p. 48), since "these tales concern universal human problems, especially those problems that occupy the mind of a child" (Bettelheim, 1985, p. 43).

According to Bruno Bettelheim, the existential problem, constituting the most important domain of life, corresponds to the children's way of thinking and their imagination, since the characters are not ambivalent, but rather clear-cut, black and white. Even though evil is presented as attractive, the ending of the fairy tale expresses the need for justice to triumph and for evil-doers to be punished, which is encoded in the child's psyche. The world is generally a bad place, but fairy tales give hope that a good person can find a way out of a difficult situation. "A fairy tale records - in a fantastic form - the folk views on interpersonal relations, presents the ideals of good and justice, and the evaluation criteria of human actions" (Tyszkowa, 1974, p. 28). Ewa Sowa-Behtane emphasises that "axiological education, focused on teaching the students about the world of values, becomes a process of gaining knowledge on values - knowledge, which should be internalised and converted into worldly wisdom. Wisdom involves the ability to distinguish between good and evil, namely the determinants of axiological space, which cover, on the one hand, positive values, and on the other hand, negative values" (Sowa-Bethane, 2015, p. 99). Children's fairy tales make for a suitable tool that is recommended for use in axiological education ${ }^{1}$.

Drama, as a method activating the pupil in the education process, also helps children better understand the fairy tales or other literary texts.

\footnotetext{
${ }^{1}$ Beata Kosová writes in more detail about education, placing it in the philosophical and global context in her book Filozofické a globalne súvislostiedukácie (Kosová, 2013).
} 
Barbara Thieme, in the article entitled Metoda dramy na lekcjach języka polskiego (Drama method in Polish language lessons) (Thieme, 1988, pp. 4446), discusses the forms of work that may prove useful during lessons devoted to analysis and interpretation of text:

- interviews with protagonists of the readings, aimed at presenting the literary character, draw attention to this character's different personality aspects;

- human sculptures - force students to engage in creative thinking, and also require justification of a given gesture, mimics, stance; particularly useful for character description, or to draw attention to the emotional aspect of the work or to reinforce abstract terms;

- playing sculptors and materials tightens cooperation between children and develops their imagination;

- trying to make the children interested in the text prior to its reading, e.g. by presenting an illustration related to the subject matter of the work; the students would try to explain the situation presented in the picture;

- $\quad$ adding single words associated with a given keyword related to the text (e.g. names of the protagonists);

- using voice intonation - the students say one simple sentence in various intonations (e.g. with joy, anger, enthusiasm, shyly); the other class participants try to guess the type of person they are dealing with; this kind of lessons enrich character description through voice and mimics, as well as help practice how to correctly interpret a given statement;

- pantomime has a great cognitive value; it can be used e.g. after discussing the text, as its summary;

- one student presenting two literary characters - the child engages in an improvised dialogue with himself;

- speaking about poetry with its simultaneous illustration through movement.

\section{Drama activities in Polish language early childhood education}

Below, we present a detailed description of drama techniques we used during a lesson on analysis and interpretation of Andersen's fairy tale The Snow Queen. These techniques included: individual and group human sculptures, drawing, mini-discussion, role-playing, interview with the main protagonist.

Building human sculptures consists in collective work guided by the teacher's instructions. The tasks of building group human sculptures are always prepared in advance by me and recorded on sheets of paper. Each group receives 
a card with an instruction, usually related to a specific fragment of the book. The task of the students building the sculpture is to present - using body language, but in a static manner (the sculpture cannot move) - a certain situation from the concerned work. The students outside the scene are helped guess the sense of the images through questions addressed thereto, such as: Is this image clear for you?, What does it present?, Can you guess the roles assumed by your friends?, Who is presenting which character in this scene?, Which fragment of the concerned text is it (e.g. initial or final)?, Who can retell this fragment for us?, etc.

Drawing is one of the artistic and manual techniques in drama, which consists in the students drawing or painting individually or in small groups, using various materials, such as crayons, markers, paints. Drawing allows the students to particularise their ideas, stimulates their imagination and develops the ability to observe and, at the same time, does not require any artistic skills.

Mini-discussion usually concerns a specific issue. Thanks to this method, the third-graders learn logical association and how to properly draw conclusions, as well as realise what they have learned.

The "role-playing" technique consists in a student playing the role of a literary protagonist and assuming his way of thinking, empathising with him, thus building an emotional connection with the protagonist. The "role-playing" student has the opportunity to identify with other people, directly experience a given situation, look at it from a different point of view. As a result, he develops the ability to solve problems, make decisions and formulate own judgments. Therefore, the student, while assuming the role of a literary protagonist, is familiar with his vices and virtues, however, he has to face his own emotions, accompanying the acting out of the role. This requires empathy and understanding of the motivation of the literary character. When role-playing, the student also invokes his own life experiences, thus gaining more awareness of the motivations for his own choices, the way of thinking and acting.

Interview involves asking the right questions and answering them. During an interview, the psychological portrait of the protagonist is specified, and the students, by observing their own reactions and the behaviour of their friends, gain valuable knowledge about another human being, especially his emotions and experiences.

We gave a lesson on: Truth and fantasy in the fairy tale "The Snow Queen" by $H$. Ch. Andersen in the 3rd grade of primary school, under Polish language education. Drama activities were an element of the cycle of lessons devoted to analysis of the work of Hans Christian Andersen. Below, we give an account of the course of an authentic lesson, thus the account is written in the first-personplural point of view. 
At the beginning of the lesson, the students were asked to, using the available instruments (flutes, pipes, bells, xylophones), choose how to use one of them and try to find the proper sounds emphasising the nature of the situation and illustrating: fantastical events (extraordinary music) and realistic events (more simplistic music).

In order to defuse the tension typical of the school environment, we also suggested exercises for focusing and stimulating the imagination:

a) introduction to the fairy tale land "Once upon a time...",

b) building individual human sculptures for the following keywords: king - wizard princess - fairy.

The point was to indicate the difference between realistic and imaginary figures. The characters do not really exist, they are fictitious, made-up, although a king is more ordinary than a wizard, and a princess is more believable than a fairy.

In the central part of the lesson, we reminded the students of the distinction introduced beforehand - between the following concepts: fiction and fantasy, indicating the superiority of fiction, and we also proposed another game - painting a portrait of the Snow Queen (after prior thorough reading of her description in the text).

Then, we divided the students into five groups. Each of them was instructed to build immobile human sculptures, illustrating a specific fragment of the Andersen's fairy tale. The first two groups were supposed to present realistic scenes, while the other three - fantastical scenes. Particular groups did not reveal their intentions until the presentation of the human sculptures. During the presentation, the other teams tried to predict the meaning of the presented images.

Group I: Children playing in the garden.

Group II: Sleighing.

Group III: Kay pierced with the mirror shard.

Group IV: Gerda's conversation with flowers.

Group V: Kay and Gerda meeting in the Snow Queen's palace.

We noted that, in the course of this drama exercise, human sculptures stimulated the students' imagination, evoked emotions. When describing the human sculptures, the students verbalised their feelings, using rich vocabulary. Since this fragment of the lesson involved problems presented further on, it was a preparation for the role-playing and the problem analysis.

Then, we offered the students to meet the heroine of the fairy tale. After the entire class expressed its consent, a selected student played the role of Gerda and briefly presented the story of the protagonist in the form of a few sentences.

Here is a sample monologue of the student: 
My name is Gerda. I will tell you a short history of my friendship with Kay. When Kay was a little boy, I used to play with him in the garden, and in the winter, we sleighed together.

One day, Kay disappeared. I decided to find him and so I went on a journey. Before I reached the Queen's palace, I had many adventures.

The student's story was interrupted by questions of other students. We noticed that the interview technique not only helped develop thinking and imagination, and was an opportunity for a speaking exercise, but also deepened interpretation of the text, due to personal involvement of the student, who had to demonstrate her familiarity with the text and, while playing the character, create her own story based on the Andersen's fairy tale.

The children asked various questions, involuntarily learning how to properly formulate them. They asked both important and less important questions, but still shed new light on the protagonist from different angles. For instance:

- What helped you survive in difficult situations when searching for Kay?

- What did you feel when Kay did not recognise you in the Queen's palace?

- Do you like nature, animals?

Then, the student was brought back from the role she played.

The summary of the lesson constituted a mini-discussion, during which the students tried to answer the following question: What does the fairy tale "The Snow Queen" teach us?

We noted that active participation in the mini-discussion allowed the students to better understand the text and interpret it in contexts contemporary for them (e.g. personal, social experiences). The students noticed that the fairy tale contains a universal message - good (Gerda's attitude) prevails over evil (the mirror shard in Kay's heart). During the mini-discussion, the students explored the motivations and reasons for the behaviour of the presented characters. It was also clear that this drama element provoked the young readers to exercise maximum mental effort, to spontaneously exchange thoughts with each other.

The last element in the course of the described drama activities was assigning the following homework to the students: Create and write a short story, in which the hero/heroine changes for the better.

\section{Conclusion}

It is beyond doubt that drama activities with the use of drama techniques: individual and group human sculptures, role-playing, interview, and drawing, "livened up" the text through action, allowed the children to connect the discussed 
matters with their personal experiences, helped them better understand the protagonist. During the mini-discussion, the students often discovered the motivations and reasons for the behaviour of the presented character. It turns out that drama helped the children both experience the reading, as well as understand the problems that the heroine of the Andersen's fairy tale had to face. Drama, just like the fairy tale itself, becomes "the source of relief and release of the accumulated tension through a substitute experience, as a result of identifying with the protagonist" (Tyszkowa, 1974, no. 3, p. 30).

On the other hand, our role was completely different than in a traditional lesson. We encouraged students to display non-verbal and verbal behaviours. Students, who wanted to take active part in the drama exercises, had to previously thoroughly read the literary text, try to specify the traits of the discussed character and understand this character's motivations.

The conducted lesson convinced us that drama not only involved the students emotionally, but also intellectually.

\section{References}

Andersen, H.Ch. (1956). Królowa Śniegu. In: Ibidem: Baśnie (pp. 119-145). Warszawa: Państwowy Instytut Wydawniczy.

Bettelheim, B. (1985). Cudowne i pożyteczne: o znaczeniach $i$ wartościach baśni. Vol. 1. Warszawa: Państwowy Instytut Wydawniczy.

Kosová, B. (2013). Filozofické a globalne súvislostiedukácie. Banská Bystrica: PF UMB.

Kuliczkowska, K., Tylicka B. (Eds.) (1979). Nowy stownik literatury dla dzieci i młodzieży. Warszawa: Wiedza Powszechna.

Laskowska, J. (2007). Rozwój aktywności twórczej dzieci w sferze języka. Kraków: Wydawnictwo Impuls.

Ogłoza, E. (2014). Wokót opowieści Hansa Christiana Andersena. O radości czytania. Katowice: Wydawnictwo Uniwersytetu Śląskiego.

Papuzińska, J. (1997). Stare i nowe mity dzieciństwa - od Gerdy i Kaya do „Kukurydzianych dzieci”. In: Hempowicz, M. (Ed.) Andersen - baśń wobec świata. Materiały z sesji literackiej. Gdańsk, 21-22 kwietnia 1995 (pp. 40-45). Gdańsk: Nadbałtyckie Centrum Kultury.

Sowa-Behtane, E. (2015). Młodzież ponowoczesna. Kraków: Akademia Ignatianum/ Wydawnictwo WAM.

Thieme, B. (1988). Metoda dramy na lekcjach języka polskiego. Oświata $i$ Wychowanie, 13, 44-46.

Tuszyńska-Chechłacz, B. (1986). Dzieciństwo jest światem poezji. Rozmowa z Danutą Wawiłow. Wychowanie w Przedszkolu, 6, 335-343.

Tyszkowa, M. (1974). Wychowawcze oddziaływanie literatury pięknej w okresie dzieciństwa i dorastania. Kwartalnik Pedagogiczny, 3, 23-34. 